\title{
Publisher Correction: Single-cell RNA-seq reveals cell type-specific transcriptional signatures at the maternal-foetal interface during pregnancy
}

\author{
Andrew C. Nelson, Arne W. Mould, Elizabeth K. Bikoff \& Elizabeth J. Robertson
}

Nature Communications 7:11414; doi: 10.1038/ncomms11414 (2016), Published 25 Apr 2016; Updated 23 Nov 2018

In the original version of this Article, the accession codes section within the Methods was inadvertently omitted. This section has now been added in both the PDF and HTML versions of the Article.

\begin{abstract}
(c) (1)
Open Access This article is licensed under a Creative Commons Attribution 4.0 International License, which permits use, sharing, adaptation, distribution and reproduction in any medium or format, as long as you give appropriate credit to the original author(s) and the source, provide a link to the Creative Commons license, and indicate if changes were made. The images or other third party material in this article are included in the article's Creative Commons license, unless indicated otherwise in a credit line to the material. If material is not included in the article's Creative Commons license and your intended use is not permitted by statutory regulation or exceeds the permitted use, you will need to obtain permission directly from the copyright holder. To view a copy of this license, visit http://creativecommons.org/licenses/by/4.0/
\end{abstract}

(C) The Author(s) 2018 